\title{
JARINGAN KOMUNIKASI DI USAHA KECIL DAN MENENGAH TRIS FLOWER JAMBANGAN SURABAYA
}

\author{
Thevani Clarine Angela, Brigitta Revia S. F, Yuli Nugraheni
}

Fakultas Ilmu Komunikasi Universitas Katolik Widya Mandala Surabaya Jalan Dinoyo 42-44, Surabaya, 60265

e-mail : thevani98clarine@gmail.com, gita@ukwms.ac.id, yulinugraheni@ukwms.ac.id

\begin{abstract}
This study aims to determine the communication network at Small and Medium Enterprises Tris Flower Jambangan Surabaya which has a waste recycling management process that is sorting raw materials, cleaning or washing, designing models, cutting materials and sewing. This study explains the process of forming a communication network that starts from two-way communication and then develops into reciprocal communication so that it can form a convergence communication model. This study uses a network analysis method, which aims to assist researchers in making a relationship map (mapping) through a matrix and sociogram. Through this sociogram we can know the role of the network including Components, Clicks, Bridges, Hubs, Cutpoints, Isolates. The results of this study are the roles that appear in the waste recycling processing network namely; (1) sorting raw materials there are roles of Clicks, Cutpoints, Bridges, and Hubs, (2) cleaning and washing, there is the role of Hubs, (3) designing models or designs there are roles of Clicks, Isolate, Cutpoints, and Hubs, (4) cutting of materials there is the role of Clicks, Cutpoints, and Hubs, (5) sewing there is the role of Isolate, and Hubs.
\end{abstract}

Keywords: Communication Network, Small and Medium Enterprises in Tris Flower Jambangan.

\section{Abstrak}

Penelitian ini bertujuan untuk mengetahui jaringan komunikasi pada Usaha Kecil dan Menengah Tris Flower Jambangan Surabaya yang memiliki proses pengelolahan daur ulang sampah diantaranya; pemilahan bahan baku, pembersihan atau pencucian, perancangan model atau desain, pemotongan bahan dan penjahitan. Penelitian ini menjelaskan mengenai proses terbentuknya jaringan komunikasi yang berawal dari komunikasi dua arah kemudian berkembang menjadi komunikasi timbal balik sehingga dapat membentuk model komunikasi konvergensi. Penelitian ini menggunakan metode analisis jaringan, yang bertujuan membantu peneliti dalam membuat peta hubungan (mapping) melalui matriks dan sosiogram. Melalui sosiogram tersebut dapat diketahui peranan jaringan meliputi Komponen, Klik, Bridges, Hubs, Cutpoints, Isolate/Pemencil, Hasil dari penelitian ini peranan yang muncul pada jaringan proses pengolahan daur ulang sampah yakni (1) pemilahan bahan baku terdapat peranan Klik, Cutpoint, Bridge, dan $H u b s$, (2) pembersihan dan pencucian terdapat peranan Hubs, (3) perancangan model atau desain terdapat peranan Klik, Isolate/Pemencil, Cutpoint, dan Hubs, (4) pemotongan bahan terdapat peranan Klik, Cutpoint, dan Hubs, (5) penjahitan terdapat perananan Isolate/Pemencil, dan Hubs.

Kata kunci: Jaringan Komunikasi, Usaha Kecil dan Menengah Tris Flower Jambangan 


\section{Latar Belakang}

Sejak tahun 1950, jumlah produksi sampah plastik terus meningkat. Data ScienceMag menyebutkan bahwa di tahun 2015, jumlah produksi sampah plastik mencapai hingga angka 381 juta ton per tahun. Kini, produksi sampah plastik yang terus meningkat tersebut menjadi permasalahan lingkungan yang serius.

Menurut data Badan Pusat Statistik tentang Pengelolaan Sampah di Indonesia pada tahun 2017, pulau Jawa memiliki produksi sampah per hari yang cukup tinggi, antara lain Surabaya yang menghasilkan sampah $9.896,78 \mathrm{~m}^{3}$ per hari dan Jakarta menghasilkan sampah sebanyak 7.164,53 $\mathrm{m}^{3}$ per hari. Proyeksi penduduk Indonesia menunjukkan angka penduduk yang terus bertambah tentunya akan meningkatkan jumlah timbunan sampah. Oleh karena itu, setiap negara perlu secara substansial mengurangi timbunan sampah melalui sebuah pencegahan, pengurangan, daur ulang, dan penggunaan kembali atau recycle.

Dalam upaya pengurangan timbunan sampah yang terus meningkat, pemerintah kota atau daerah turut andil bagian didalamnya. Salah satunya dapat dilakukan dengan cara melakukan 3R (reduce, reuse, recycle). Saat ini pemerintahan kota (Pemkot) Surabaya yang sedang melakukan 3R dengan memulai program-program lingkungan hidup. Ada beberapa program dari kota kedua terbesar di Indonesia ini untuk menjaga lingkungan hidup, misalnya; Merdeka Dari Sampah (MDS), dan Surabaya Green and Clean (SGC).

Pada program Merdeka Dari Sampah atau dikenal dengan MDS ini merupakan salah satu program yang menjalankan upaya pengurangan sampah yang sulit terurai. Seluruh RT dan RW se-Surabaya dapat mengikuti program tersebut. Dalam program MDS ini terdapat berbagai lomba yang berkaitan dengan sampah. Pemerintah kota memiliki kategori penilaian tersendiri untuk RT atau RW yang menjadi pemenang, tentunya hal tersebut dilakukan untuk memotivasi warga Surabaya agar memiliki rasa peduli terhadap lingkungan serta tetap menjaga Kota Pahlawan menjadi lebih bersih.

Program Surabaya Green and Clean (SGC) merupakan program Pemerintah Kota Surabaya yang berada di bawah Dinas Kebersihan dan Pertanian. Pada awal program SGC ini dilaksanakan, ia bekerjasama dengan Yayasan Unilever Indonesia dan berbagai media dengan tema "Kampungku Bersih Bebas Penyakit". Saat ini program SGC berganti nama menjadi SSC atau Surabaya Smart City. 
Program ini memiliki tujuan sebagai wadah bagi kampung-kampung tiap kecamatan di Surabaya untuk unjuk gigi dalam pengelolaan sampah dan lingkungan kampungnya. Seluruh kampung yang berada di Surabaya dapat mendaftar sebagai peserta dalam program dan perlombaan ini. Pada tahun 2005 tersebut yang menjadi juara ialah Kecamatan Jambangan.

Setelah menjuarai berbagai juara, secara resmi pada tahun 2015 UKM Tris Flower ditetapkan menjadi Sentra Kerajinan Daur Ulang Kota Surabaya. Namun, statusnya sebagai sentra daur ulang di kota Surabaya membuatnya menerima permintaan pasar lebih banyak. Namun para anggota UKM Tris Flower mengalami permasalahan yang sama yaitu minimnya informasi bagi anggota dalam pengolahan sampah. Permasalahan tersebut dikarenakan belum meratanya informasi mengenai tahapan proses pengolaan sampah yang mana proses pengolahan sampah terdapat 5 (lima) tahapan yaitu pemilahan bahan, pembersihan atau pencucian, perancangan model, pemotongan, dan penjahitan. Proses-proses tersebut didapatkan para anggota melalui hasil kesepemahaman informasi antar para anggota. Kesepemahaman informasi tersebut didapat dilakukan dengan metode analisis jaringan komunikasi yang mana tergambar dari arus informasi yang merupakan upaya dari masing-masing anggota untuk mencari dan mendapatkan informasi mengenai pengolahan sampah menjadi sebuah kerajinan.

Proses pertukaran informasi untuk mencapai pemahaman yang sama terjadi dari dua orang atau lebih menggambarkan adanya jaringan yang muncul sebagai akibat kebutuhan informasi. Proses pertukaran informasi yang terjadi bisa lewat tatap muka secara langsung atau melalui media komunikasi (Hertanto, 2016 : 56). Ditegaskan kembali dalam jurnal Zulkarnain bahwa jaringan komunikasi tidak akan terbentuk tanpa adanya pertemuan, hal tersebut menunjukkan pentingnya tatap muka dalam difusi pengetahuan (Zulkarnain, 2015 : 116)

Pada dasarnya individu maupun kelompok kerja dihubungkan ke dalam suatu sistem melalui komunikasi dalam organisasi. Jaringan sendiri menjelaskan kepada kita bagaimana kelompok atau organisasi tersebut tetap bersatu atau terikat satu sama lain (Cindoswari, A. R., 2016 : 131). Menurut Thomas J. Atchison dan Winston W. Hill dalam buku Effendy yang berjudul Human Relation \& Public Relation, "organisasi adalah sistem yang 
dipolakan orang untuk melaksanakan tujuan atau untuk mencapai sasaran" (Effendy, 2009 : 1). Pendekatan sistem memainkan peran yang begitu penting terhadap organisasi; salah satunya sistem terbuka. Dalam sistem terbuka, sistem tersebut memungkinkan terjadinya pertukaran bahan, informasi atau energi di antara individu maupun kelompokkelompok di dalam lingkungannya (Effendy, 2009: 3).

Hasil dari pertukaran informasi ialah jaringan komunikasi yang memiliki dua bentuk yaitu formal dan informal. Secara formal berarti pola hubungan berorientasi pada struktur organisasi (Morissan, 2009 : 50). Penentuan arus informasi pada jaringan formal berdasarkan struktur organisasi dari atasan ke bawah atau sebaliknya (Ruliana, 2014 : 80). Sedangkan secara informal berarti peserta komunikasi berkomunikasi tanpa memperhatikan posisi atau jabatan mereka dalam organisasi (Muhammad, 2017 : 126). Komunikasi informal dapat membentuk kelompok informal ketika dilakukan secara rutin dan berkelanjutan. Fungsi dari komunikasi informal ialah memelihara hubungan sosial persahabatan kelompokinformal, yakni penyebaran informasi yang bersifat pribadi dan privat contohnya; isu, gossip, atau rumor (Fitriani, 2016 : 276).

Pada dasarnya jaringan komunikasi merupakan pemetaan hubungan atau "mapping" dilakukan terhadap individu maupun kelompok sosial yang mana merupakan komponen sistem. Tujuan dari analisis jaringan komunikasi ialah untuk mengambarkan pola dari arus informasi yang terbentuk dalam individuindividu sebuah sistem (Kriyantono, 2012 : 319). Selain menggambarkan pola arus informasi, jaringan komunikasi juga dapat menjelaskan tiap individu kedalam elemen jaringan komunikasi karena jaringan juga menunjukkan bahwa distribusi peranan penting untuk keefisienan berfungsinya suatu organisasi (Pangestu, 2015 : 4). Menurut Eriyanto, terdapat beberapa elemen atau peran, yaitu 1) Komponen, 2) Klik, 3) Bridges, 4) Hubs, 5) Cutpoints, dan 6) Pemencil atau Isolate (Eriyanto, 2014 : 46). Sementara dalam buku Komunikasi Organisasi penelitian jaringan komunikasi memiliki beberapa bagian yaitu 1) Anggota klik, 2) Penyendiri, 3) Jembatan, 4) Penghubung, 5) Penjaga Gawang, 6) Pemimpin pendapat, 7) Kosmopolit (Pace, 2015:183).

Fokus penelitian jaringan komunikasi ditujukan untuk menggambarkan pola informasi pada setiap anggota di dalam 
suatu sistem atau organisasi. Melalui pola tersebut peneliti dapat mengetahui relasi antar anggota serta elemen yang sesuai pada masing-masing aktor. Oleh karena itu jaringan komunikasi diperlukan untuk melihat peran masing-masing anggota dalam organisasi yang mana kesuksesan suatu organisasi saat ini tidak lagi mengandalkan hierarki atau birokrasi organisasi, melainkan organisasi yang mengedepankan relasi antar anggota organisasinya.

Tujuan dari penelitian ini adalah untuk menggambarkan pola relasi dan peran yang terdapat didalam UKM Tris Flower pada masing-masing tahapan pengolahan sampah (pemilahan bahan, pembersihan atau pencucian, perancangan model, pemotongan, dan penjahitan) di sentra kerajinan daur ulang sampah yaitu UKM Tris Flower Jambangan Surabaya.

\section{Teori}

\section{Komunikasi Dua Arah}

Proses komunikasi dua arah atau interaksi atau sirkuler merupakan proses komunikasi dimana dapat terjadi pergantian peran antara komunikator dan komunikan karena adanya unsurumpanbalik / feedback. Maksud dari perubahan peran tersebut ialah ketika komunikator dapat berperan sebagai komunikan dan sebaliknya (Moerdijati, 2016 : 70).
Komunikator (source) dan komunikan (receiver) dapat saling bertukar pesan. Baik komunikator maupun komunikan saling memproduksi pesan (encoding), menafsirkan pesan (interpreting) dan menerima serta memahami pesan yang diterima (decoding). Seperti yang dikatakan tadi bahwa pada proses komunikasi dua arah ada unsur umpanbalik / feedback. Kedua pelaku komunikasi (komunikator dan komunikan) juga dapat berubah peran, komunikator dapat berubah peran sebagai komunikan, begitu sebaliknya.

\section{Komunikasi Timbal Balik}

Komunikasi timbal balik tercipta dari proses komunikasi dua arah yang terjadi secara terus-menerus. Hal tersebut diakibatkan proses komunikasi tidak berhenti begitu saja sesudah umpan balik / feedback, melainkan berbalik kembali ke peserta pertama dan pihak pertama tersebut menyusun pesan baru lagi (Kincaid, Wilbur, 1978 :104). Menurut Mulyana (2017 : 73), dikatakan sebagai umpan balik bila hal tersebut merupakan respons terhadap pesan pengirim dan bila mempengaruhi perilaku selanjutnya pengirim.

Dalam komunikasi timbal balik setiap peserta mengolah pesan-pesan yang digunakan bersama, yang satu menyusun 
dan yang lain menguraikan. Jadi kedua peserta bersama aktif. Dengan demikian setiap peserta dapat menyumbangkan nmakna mereka mengenai pesan tersebut (Kincaid, Wilbur, 1978 : 104). Dalam proses komunikasi timbal balik setiap peserta dapat berperan sebagai komunikator maupun partisipan. Peserta bersifat aktif artinya pada waktu yang sama dalam diri mereka masing-masing dapat melakukan proses encoding, interpreting, dan decoding (Moerdijati, $2016: 72)$.

\section{Komunikasi Konvergensi}

Dalam sebuah sistem, komunikasi memusat dilakukan agar tercipta saling pengertian tentang makna masing-masing pihak (Kincaid, Wilbur, 1978 : 104). Komunikasi memusat atau konvergensi merupakan pengembangan dari komunikasi timbal balik. Komunikasi konvergensi biasanya dikenal dengan model melingkar. Menurut Rogers dalam Kriyantono, ia mendefinisikan model komunikasi konvergen merupakan sebuah proses pemusatan informasi, dimana informasi dibagi oleh para partisipan agar dapat mencapai kesepemahaman (Kriyantono, 2012 : 322).

\section{Jaringan Komunikasi}

Jaringan merupakan suatu struktur sosial yang tercipta melalui komunikasi antara sejumlah individu atau kelompok (Morissan, 2009 : 50). Dalam buku Eriyanto (2014 : 5), secara sederhana mendefinisikan jaringan sebagai suatu relasi dari seperangkat aktor (bisa orang, perusahaan, lembaga, negara, dan sebagainya) dengan aktor lainnya. Komunikasi yang diciptakan antara sejumlah individu atau kelompok akan menciptakan hubungan formal maupun informal (Morissan, 2009 : 50).

Seperti yang sudah dijelaskan, relasi antar aktor satu dengan lainnya dalam struktur sosial tertentu dapat tergambar melalui studi jaringankomunikasi baik secara formal maupun informal. Secara formal berarti pola hubungan berorientasi pada struktur organisasi (Morissan, 2009 : 50). Pada jaringan formal, arus informasi ditentukan oleh struktur organisasi dari atasan ke bawah atau sebaliknya (Ruliana, 2014 : 80). Sedangkan secara informal berarti peserta komunikasi berkomunikasi tanpa memperhatikan posisi atau jabatan mereka dalam organisasi (Muhammad, $2017:$ 126).

\section{Analisis Jaringan Komunikasi}

Relasi antar aktor satu dengan lainnya dalam struktur sosial tertentu dapat tergambar melalui studi jaringan komunikasi (Eriyanto, 2014 : 5). Pemetaan hubungan biasa dikenal dengan "mapping" 
dilakukan terhadap individu maupun kelompok sosial, keduanya merupakan komponen dalam suatu sistem. Tujuan dari analisis jaringan komunikasi ialah untuk mengetahui bagaimana pola dari arus informasi yang mengalir dalami individu yang ada pada sebuah sistem (Kriyantono, 2012 : 319). Terkait dengan penulisan ini, tujuan dari mapping ialah untuk mengetahui pola interaksi atau arus informasi dalam relasi Usaha Kecil dan Menengah (UKM) daur ulang sampah di Kecamatan Jambangan Surabaya.

Sebuah jaringan memiliki beberapa elemen yang dapat menggambarkan peran seseorang atau individu dalam suatu sistem (Eriyanto, 2014 : 46-47). Beberapa elemen tersebut ialah sebagai berikut:

- Komponen

Pengelompokkan aktor (node) yang memiliki link sekurang-kurangnya satu link dalam jaringan.

- Klik

Merupakan pengelompokkan aktor yang ketat. Klik ditandai jika anggota dari aktor saling memiliki relasi satu sama lainnya. Beberapa syarat klik yang tertulis di buku Teknik Praktis Riset Komunikasi (Kriyantono, 2012 : 326) yaitu: (1) setiap klik paling sedikit terdiri dari tiga anggota, (2) setiap anggota klik tidak mempunyai $50 \%$ hubungan, (3) semua angota klik harus berhubungan satu sama ain secara langsung maupun tidak langsung, artinya tidak memerhatikan arah hubungan.

\section{- Bridges}

Merupakan penghubung dua kelompok terpisah dalam jaringan. Jembatan adalah link (edge/ties) yang menghubungkan dua kelompok terpisah dalam suatu jaringan. Tanpa jembatan (bridge) tersebut, maka sekumpulan aktor tersebut tidak terhubung menjadi suatu jaringan.

- Hubs

Menurut Golbec dalam buku Eriyanto, hubs merujuk pada aktor (node) yang memiliki koneksi paling banyak dalam jaringan.

\section{- Cutpoints}

Menurut Borgatti dan DeJody dalam buku Eriyanto, cutpoint ialah aktor yang menjadi perekat dari jaringan. Cutpoints mirip dengan jembatan (bridge) yang mengubungkan aktor-aktor. Perbedaan cutpoint dengan bridge ialah jembatan merupakan link dari dua aktor, sedangkan cutpoint pada aktor (node).

- Isolate atau Pemencil

Individu atau aktor yang tidak terlibat dalam jaringan komunikasi, disini ia tidak memilih maupun dipilih sebagai pasangan komunikasi oleh individu lainnya, individu ini dinamakan pemencil (isolate). 
Berbagai elemen telah dijelaskan diatas antara lain Komponen, Klik, Bridges, Hubs, Cutpoints, dan Pemencil atau Isolate akan diketahui, melalui proses analisa jaringan yaitu membuat peta hubungan dalam bentuk Sosiogram.

Usaha Kecil dan Menengah (UKM) di Indonesia

Usaha Kecil dan Menengah atau UKM tidak hanya ada di negara-negara maju, namun saat ini juga sedang berkembang di negara berkembang seperti di Indonesia. Keberadaan UKM memiliki peran penting dalam memberi kontribusi positif terhadap penanggulangan masalahmasalah ekonomi dan sosial. Contohnya seperti tingginya tingkat kemisikinan, besarnya tingkat pengangguran terutama dari golongan masyarakat berpendidikan rendah, dan lain-lain (Agustina, $2015: 6$ ). Hal tersebut membuktikan bahwa peranan Usaha Kecil dan Menengah ini juga berperan pada perekonomian nasional selain itu juga sebagai penyerapan tenaga kerja (Sulastri, 2016 : 13).

Di Indonesia, Usaha Kecil dan Menengah memiliki pengertian masingmasing yang dijelaskan dalam Pasal 1 UU Usaha Mikro, Kecil dan Menengah No. 20 Tahun 2008. Dalam pasal tersebut mendefinisikan "usaha kecil sebagai usaha ekonomi produktif yang berdiri sendiri, yang dilakukan oleh orang perorangan atau badan usaha yang bukan merupakan anak perusahaan yang dimiliki, dikuasai, ....". Sedangkan "usaha menengah adalah usaha ekonomi produktif yang berdiri sendiri, yang dilakukan oleh orang perorangan atau badan usaha yang bukan merupakan anak perusahaan atau cabang perusahaan yang dimiliki, dikuasai,...." (Agustina, $2015: 4$ ).

\section{Metode}

Penelitian ini menggunakan pendekatan kuantitatif dengan jenis penelitian deskriptif untuk menganalisis jaringan komunikasi pada suatu sistem. Secara umum, pendekatan kuantitatif digunakan karena menggambarkan atau menjelaskan suatu masalah yang hasilnya (Kriyantono, 2012 : 55). Dalam penelitian ini, peneliti menggunakan penelitian deskriptif. Penelitian tersebut digunakan untuk menjelaskan tiap-tiap elemen jaringan komunikasi yang terdapat di UKM Tris Flower.

Metode yang digunakan dalam penelitian ini adalah metode analisis jaringan. Metode ini memusatkan perhatian pada relasi. Relasi antar aktor satu dengan lainnya dalam struktur sosial tertentu dapat tergambar di dalamnya (Eriyanto, 2014 : 5). Tujuan dari analisis jaringan komunikasi ialah untuk mengetahui bagaimana arus informasi 
terpolakan yang mengalir dalam individuindividu pada sebuah sistem.

Penelitian ini merupakan penelitian dengan melakukan "mapping" atau pemetaan hubungan, sehingga dalam penelitian ini peneliti menggunakan teknik Total Sampling. Dalam teknik Total Sampling peneliti mengambil keseluruhan jumlah dari populasi sebagai sampel yaitu sebanyak 12 orang. Apabila hanya mengambil sebagian dari jumlah keseluruhan, dapat membuat sistem atau arus informasi dalam jaringan komunikasi tersebut terputus. Populasi dan sampel dalam penelitian ini ialah pemilik, pengelola, sekretaris, bendahara dan beberapa anggota aktif / pasif UKM Tris Flower.

Teknik pengumpulan data yang digunakan dalam penelitian ini adalah dengan menyebarkan kuesioner atau angket. Kuesioner adalah daftar pertanyaan yang harus diisi oleh responden. Tujuan penyebaran angket adalah mencari informasi yang lengkap mengenai suatu masalah dari responden (Kriyantono, 2012 : 97). Dalam kuesioner atau angket, peneliti akan memberikan pertanyaan seputar identitas atau karakteristik responden, serta beberapa pertanyaan terbuka terkait pengolahan sampah hingga menjadi berbagai kerajinan. Penelitian ini menggunakan pertanyaan terbuka bertujuan agar mendapatkan data yang valid dari para responden.

\section{Pembahasan}

\section{Sosiogram Jaringan Komunikasi dalam} Pemilahan Bahan Baku

\section{$\mathrm{N}=12$}

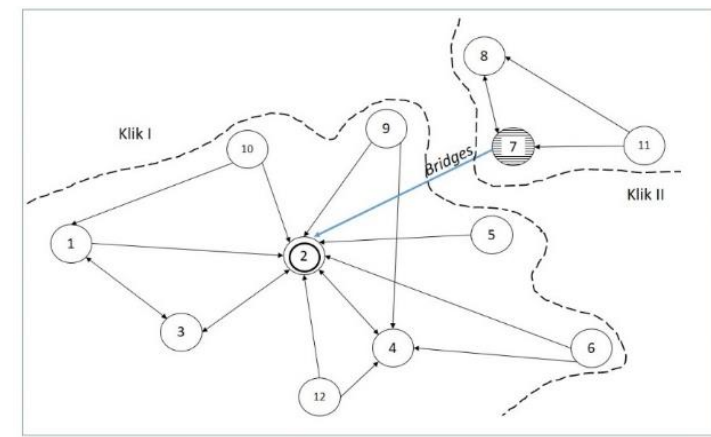

Gambar 1 Sosiogram Informasi Pengolahan Sampah Daur Ulang dalam proses Pemilihan Bahan Baku

\section{Keterangan:}

a. $\bigcirc$ : Aktor / Komponen

b. $\ominus$ : Cutpoints

c. $\bigcirc$ :Isolate / Pemencil

d. $\bigcirc$ : Hubs

e. $\rightarrow$ : Satu Arah

f. $\leftrightarrow$ : Dua Arah

g. - - : Batasan Klik

h. $\quad$ : Bridges

Pada Gambar 1, sosiogram tersebut menunjukkan bagaimana arah komunikasi yang terjadi dalam sebuah sistem jaringan dalam proses penyebaran informasi terkait pemilahan bahan baku yang merupakan salah satu tahapan pengolahan sampah daur ulang di Usaha Kecil dan Menengah (UKM) Tris Flower Jambangan. 
Dalam sosiogram ini menggambarkan relasi antara 12 komponen atau aktor yang tergabung dalam UKM Tris Flower. Sosiogram yang tergambar menunjukkan bahwa terdapat 2 (dua) klik yang dipisahkan oleh batasan klik. Klik I beranggotakan aktor nomor 1-2-3-4-5-6-910-12 dan Klik II beranggotakan aktor nomor 7-8-11. Kedua Klik memenuhi syarat Klik seperti yang tertulis di buku Teknik Praktis Riset Komunikasi (Kriyantono, 2012 : 326) yaitu: (1) setiap klik paling sedikit terdiri dari tiga anggota, (2) setiap anggota klik tidak mempunyai $50 \%$ hubungan, (3) semua angota klik harus berhubungan satu sama lain secara langsung maupun tidak langsung, artinya tidak memerhatikan arah hubungan. Klik II terbentuk karena aktor nomor 7-8-11 tersebut memiliki pekerjaan yang sama yaitu sebagai ibu rumah tangga memiliki rumah yang berdekatan sehingga lebih mudah mendapatkan informasi mengenai pemilahan bahan baku pembuatan kerajinan daur ulang.

Pada Gambar 1. aktor nomor 7 yaitu Nur Janati (52) juga berperan sebagai cutpoint antara Klik I dan Klik II. Dalam jaringan ini ia menghubungkan Klik I dengan aktor nomor 2 yaitu Lusiani (45) yang termasuk dalam Klik II. Alasan Nur mencari informasi mengenai pemilahan bahan baku kepada Lusiani ialah karena Nur memiliki kedekatan dengan Lusiani yang menjadi pengelola UKM Tris Flower. Selain itu Lusiani juga lebih sering berkomunikasi secara langsung dengan bank sampah dan pemasok sampah daur ulang lainnya. Dengan adanya Nur sebagai cutpoint akan membantu tersampaikannya informasi dari klik I ke klik II, begitu sebaliknya. Selain terdapat cutpoint yang menjadi penghubung antar kelompok, dalam sosiogram juga terdapat link jembatan atau bridge yang tergambar menghubungkan dua aktor yaitu aktor 7 dan aktor 2 .

Pada Gambar 1. juga menunjukkan bahwa terdapat peran hubs ditujukan pada nomor 2 yaitu Lusiani. Lusiani memiliki peran hubs karena memiliki koneksi paling banyak dalam jaringan. Dimana ia memiliki sembilan link dari aktor nomor 13-4-5-6-7-9-10-12, jumlah tersebut terbanyak dibandingkan dengan aktor lainnya. Aktor yang memilih Lusiani memiliki alasan karena ia merupakan pengelola yang berkomunikasi secara langsung dengan bank sampah dan pemasok sampah daur ulang lainnya. Menurut hasil wawancara dengan aktor nomor 1 yaitu Sutrisno (24 Oktober 2019 di UKM Tris Flower), ia mengatakan: 
"Kalau memilah bahan baku biasanya di pilah lagi sama $\mathrm{Bu}$ Tris, kadang-kadang dibantu Bu Sur juga. Bahan mentahnya itu dari bank sampah atau ada bapak-bapak pengepul sampah yang datang"

Peran hubs (aktor dengan koneksi link paling banyak) yang ditujukan pada aktor nomor 2, karena dapat dikatakan menjadi pimpinan informal karena pendapatnya dapat diterima dan diikuti oleh para aktor lainnya. Hal tersebut karena Lusiani merupakan pengelola sekaligus ia lebih berpengalaman. Jika dilihat dari tahun bergabung, Lusiani merupakan salah satu dari tiga orang yang bergabung dan membangun UKM pada tahun 2006. Pengalaman tersebut membuat Lusiani dapat memberikan dan menyampaikan informasi mengenai pemilahan bahan baku kepada anggota lainnya. Biasanya ia melakukan pemilahan juga berdasarkan permintaan pelanggan.

Pada jaringan komunikasi Usaha Kecil dan Menengah (UKM) Tris Flower yang berfokus pada salah satu proses pengolahan sampah daur ulang, yaitu pemilahan barang baku, terdapat 5 (lima) peranan yang terbentuk dari hasil interaksi anggota satu sama lain. Peranan yang terbentuk dalam jaringan ini adalah Komponen, Klik, Cutpoint, Bridge dan Hubs. Kelima peranan yang terlihat merupakan aktor yang memiliki andil dalam membangun UKM Tris Flower hingga menjadi sentra kerajinan daur ulang sampah kota Surabaya. Bukan hanya pengelola yang memiliki andil, namun anggota yang merupakan warga Kecamatan Jambangan pun memiliki andil dalam hal ini.

\section{Sosiogram Jaringan Komunikasi dalam}

\section{Pembersihan / Pencucian}

$\mathrm{N}=12$

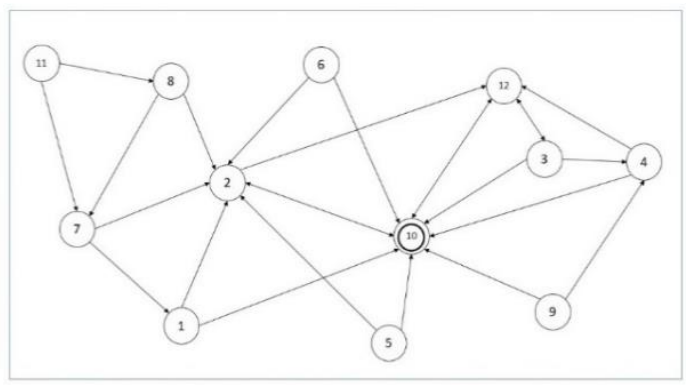

Gambar 2 Sosiogram Informasi Pengolahan Sampah Daur Ulang dalam proses Pembersihan

\section{Keterangan:}

a. $\bigcirc$ : Aktor / Komponen

b. $\ominus$ : Cutpoints

c. : Isolate / Pemencil

d. $(H u b s$

e. $\rightarrow$ : Satu Arah

f. $\leftrightarrow$ : Dua Arah

g. - - : Batasan Klik

h. : Bridges

Pada Gambar 2., sosiogram tersebut menunjukkan bagaimana arah komunikasi yang terjadi dalam sebuah sistem jaringan dalam proses penyebaran informasi terkait pembersihan dan pencucian yang merupakan salah satu tahapan pengolahan 
sampah daur ulang di Usaha Kecil dan Menengah (UKM) Tris Flower Jambangan.

Dalam sosiogram ini menggambarkan relasi antara 12 komponen atau aktor yang tergabung dalam UKM Tris Flower. Sosiogram tersebut menunjukkan bahwa sistem tidak memiliki klik, dikarenakan tidak memenuhi syarat dari klik. Seluruh aktor atau komponen aktif berinteraksi satu dengan yang lainnya. Namun dalam sosiogram ini menunjukkan adanya peran hubs didalamnya yaitu aktor nomor 10 , Alvan. Alvan memiliki link paling banyak, dimana ia mendapatkan delapan link dari aktor nomor 1-2-3-4-5-6-9-12. Menurut hasil wawancara peneliti dengan beberapa aktor yang memilih Alvan beberapa memiliki alasan jika Alvan sering melebih paham mengenai berbagai bahan baku tersebut sehingga dapat menyampaikan informasi tersebut kepada anggota lainnya yang memerlukan. Menurut hasil wawancara peneliti dengan Catur pada 05 November di UKM Tris Flower, ia mengatakan:

"Kalau untuk pencucian bahan baku plastik saya masih bisa. Tapi kalo sudah karung goni, yang tebal begitu biasa saya tanya ke Alvan. Karena kemarin waktu acara Eco School pertama saya coba cuci debunya nggak hilang-hilang. Ternyata waktu tanya Alvan harus direndam 1 minggu dulu dan ada tekniknya, pengeringannya juga lama"

Aktor Alvan merupakan anggota yang baru bergabung dengan UKM Tris Flower pada tahun 2018, namun ia sudah menguasai proses pencucian dan pembersihan. Bahan baku setelah dipilah akan dilakukan proses pembersihan atau pencucian, seperti: karung goni, botol plastik, hingga kemasan detergen. Setelah dicuci, bahan baku tersebut harus dikeringkan hingga benar-benar kering. Karena jika tidak benar-benar kering maka hasil kerajinan daur ulang sampah akan bau.

Pada jaringan komunikasi Usaha Kecil dan Menengah (UKM) Tris Flower yang berfokus pada salah satu proses pengolahan sampah daur ulang, yaitu pembersihan dan pencucian, terdapat 2 (dua) peranan yang terbentuk dari hasil interaksi anggota satu sama lain. Peranan yang terbentuk dalam jaringan ini adalah Komponen dan Hubs. Peranan yang terlihat merupakan aktor yang memiliki andil dalam membangun UKM Tris Flower hingga menjadi sentra kerajinan daur ulang sampah kota Surabaya. Anggota yang merupakan warga Kecamatan Jambangan memiliki andil dalam hal ini. 
Sosiogram Jaringan Komunikasi dalam Perancangan Model

$\mathrm{N}=12$

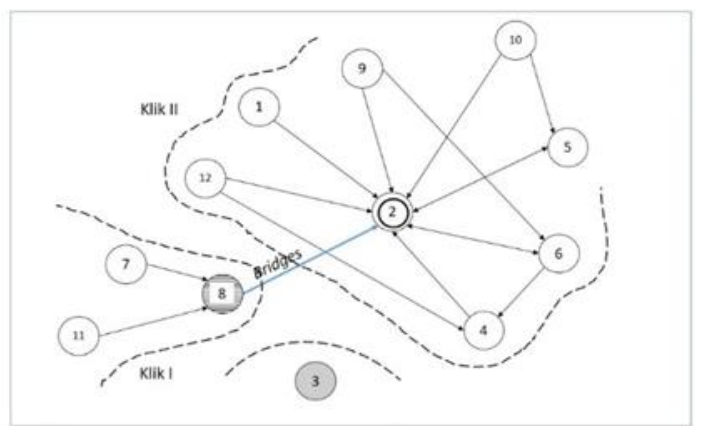

Gambar 3 Sosiogram Informasi Pengolahan Sampah Daur Ulang dalam proses Perancangan Model

Keterangan:
a. $\bigcirc$ : Aktor / Komponen
b. $\ominus$ : Cutpoints
c. $\bigcirc$ : Isolate / Pemencil
d. $\bigcirc$ : Hubs
e. $\rightarrow$ : Satu Arah
f. $\leftrightarrow$ : Dua Arah
g. - - : Batasan Klik
h. $:$ Bridges

Pada Gambar 3, sosiogram tersebut menunjukkan bagaimana arah komunikasi yang terjadi dalam sebuah sistem jaringan dalam proses penyebaran informasi terkait perancangan model atau desain yang merupakan salah satu tahapan pengolahan sampah daur ulang di Usaha Kecil dan Menengah (UKM) Tris Flower Jambangan.

Dalam sosiogram ini menggambarkan relasi antara 12 komponen atau aktor yang tergabung dalam UKM Tris Flower. Pada sosiogram yang tergambar menunjukkan adanya klik yang terbentuk dalam jaringan komunikasi mengenai perancangan model atau desain kerajinan daur ulang sampah. Klik yang terbentuk berjumlah dua klik, yaitu Klik I yang beranggotakan aktor dengan nomor 7-8-11 dan Klik II beranggotakan aktor dengan nomor 1-2-4-5-6-9-10-12. Klik I yang terdiri dari Ida Nurhayati, Nur Janati dan Riska memiliki kedekatan rumah yaitu terletak di Jambangan RT 02. Begitu pula dengan seluruh anggota pada Klik II yang memiliki kedekatan rumah yaitu terletak di Jambangan RT 01. Kedekatan tempat tinggal ini mempengaruhi seorang aktor dalam mencari informasi.

Pada Klik I terlihat jika aktor nomor 7 dan 11 mencari informasi mengenai perancangan model atau desain kepada aktor nomor 8 , hal tersebut karena aktor nomor 8 yaitu Ida Nurhayati yang lebih sering berkomunikasi dengan Lusiani aktor nomor 2, dimana Lusiani merupakan pengelola UKM Tris Flower dan Lusiani juga yang melakukan perancangan model kerajinan daur ulang. Oleh karena itu aktor nomor 8 mendapatkan peran Cutpoints, dimana peran ini merupakan perekat antar aktor 7 dan 11 kepada aktor nomor 2. Ida merupakan Ketua RT 02 di Kecamatan Jambangan. Selain itu Ida juga merupakan 
anggota yang bergabung di UKM paling lama, yaitu sejak tahun 2008. Kedua hal tersebut yang membuat Ida memiliki kedekatan dengan Lusiani.

Pada sosiogram ini juga terdapat peran jembatan yang mana merupakan suatu link. Jembatan merupakan link yang menghubungkan antara kelompok satu dan lainnya. Jembatan / Bridge dalam sosiogram ini tergambar menghubungkan dua kelompok yaitu Klik I dan Klik II melalui dua aktor yaitu aktor nomor 8 dan aktor nomor 2. Keduanya terhubung atas dasar mencari informasi mengenai proses perancangan model.

Selain terdapat Klik dan Cutpoint, pada Gambar IV.3. tergambar satu aktor yang memiliki peran Isolate atau Pemencil yaitu aktor nomor 3, Muhammad Chandra yang akrab dipanggil Chandra. Hal tersebut dikarenakan Chandra tidak memiliki link atau kontak dengan aktor lainnya di dalam jaringan. Menurut hasil wawancara peneliti dengan Lusiani pada 05 November 2019 di UKM Tris Flower, Lusiani mengatakan bahwa untuk tahapan perancangan model dan desain ini Chandra tidak ikut serta didalamnya. Chandra yang bekerja sebagai pelajar mengakui bahwa pekerjaan dalam proses perancangan model merupakan wewenang daripada individu yang memiliki hubungan langsung dengan pelanggan. Jabatannya sebagai sekretaris memiliki tugas sebagai pencatat pesanan yang sudah pasti. Sedangkan untuk berhubungan langsung dengan pelanggan untuk mengetahui model yang diinginkan pelanggan Chandra lebih menyerahkan kepada pengelola yaitu Lusiani dan penjahit. Oleh karena itu, sosiogram ini menunjukkan aktor nomor 2 yaitu Lusiani yang memiliki jabatan sebagai pengelola UKM Tris Flower memiliki peran sebagai hubs.

Aktor nomor 2 mendapatkan peran hubs karena memiliki jumlah link terbanyak yaitu delapan link (dari aktor 14-5-6-8-9-10-12). Alasan beberapa aktor mencari informasi mengenai perancangan model dan desain ke Lusiani adalah Lusiani yang akrab dipanggil $\mathrm{Bu}$ Tris ini merupakan aktor yang sering berhubungan langsung dengan pelanggan. Biasanya $\mathrm{Bu}$ Tris melakukan diskusi dan proses negoisasi kepada pelanggan mengenai desain produknya. Desain produk yang dibuat biasanya mengikuti tema dari suatu acara ataupun ketentuan mengenai lomba yang akan diikuti oleh pelanggannya. Pelanggan yang sering bekerjasama dengan UKM Tris Flower tidak hanya dari Surabaya, namun hingga keluar kota. Pihak yang bekerjasama dengan UKM yang berlokasi di Kecamatan Jambangan 
ini biasanya dari sekolahan, hingga kampung atau kecamatan. Menurut hasil wawancara peneliti dengan $\mathrm{Bu}$ Tris pada 05 November 2019 di UKM Tris Flower, ia mengatakan:

"Saya biasa kasi pilihan ke pelanggan untuk modelnya, tapi biasa mereka kurang suka karena modelnya biasa. Tapi saya yakinkan mereka kalau lolos final akan dipercantik lagi biar menang"

Pada jaringan komunikasi Usaha Kecil dan Menengah (UKM) Tris Flower yang berfokus pada salah satu proses pengolahan sampah daur ulang, yaitu perancangan model atau desain, terdapat empat peranan yang terbentuk dari hasil interaksi anggota satu sama lain. Peranan yang terbentuk dalam jaringan ini adalah Komponen,Klik, Isolate / Pemencil, Cutpoints, dan Hubs. Dalam sosiogram ini menunjukkan adanya Isolate yang tidak memiliki link dengan aktor manapun. Hal tersebut berarti Isolate tidak memiliki banyak andil dalam proses ini. Sedangkan 4 (empat)peranan yang terlihat merupakan aktor yang memiliki andil dalam membangun UKM Tris Flower hingga menjadi sentra kerajinan daur ulang sampah kota Surabaya. Bukan hanya pengelola yang memiliki andil, namun anggota yang merupakan warga
Kecamatan Jambangan pun memiliki andil dalam hal ini.

Sosiogram Jaringan Komunikasi dalam

\section{Pemotongan}

$\mathrm{N}=12$

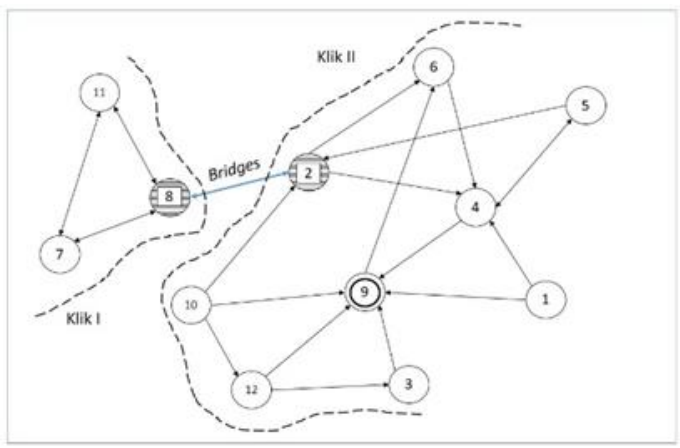

Gambar 4 Sosiogram Informasi Pengolahan Sampah Daur Ulang dalam proses Pemotongan Bahan

\section{Keterangan:}

a. $\bigcirc$ : Aktor / Komponen

b. $\ominus$ : Cutpoints

c. $\bigcirc$ : Isolate / Pemencil

d. $($ : Hubs

e. $\rightarrow$ : Satu Arah

f. $\leftrightarrow$ : Dua Arah

g. - - : Batasan Klik

h. $\quad$ : Bridges

Pada Gambar 4, sosiogram tersebut menunjukkan bagaimana arah komunikasi yang terjadi dalam sebuah sistem jaringan dalam proses penyebaran informasi terkait pemotongan bahan yang merupakan salah satu tahapan pengolahan sampah daur ulang di Usaha Kecil dan Menengah (UKM) Tris Flower Jambangan.

Dalam sosiogram ini menggambarkan relasi antara 12 komponen atau aktor yang 
tergabung dalam UKM Tris Flower. Sosiogram ini menunjukkan bahwa terdapat dua Klik yang tergambar. Klik I beranggotakan aktor nomor 7-8-11 dan Klik II beranggotakan aktor nomor 1-2-34-5-6-9-10-12. Pemotongan bahan sebagian besar dilakukan di rumah masing-masing atau di UKM Tris Flower. Oleh karena itu tempat tinggal yang berpengaruh terhadap pencarian informasi antar aktor dalam jaringan. Pada sosiogram ini Klik I dan Klik 2 terhubung oleh jembatan / Bridge, dimana menghubungkan aktor nomor 8 dan aktor nomor 2. Kedua aktor terhubung untuk menyalurkan informasi mengenai pemotongan bahan dari Klik I ke Klik 2, begitu sebaliknya.

Selain adanya link jembatan atau bridge yang menghubungkan dua kelompok, pada sosiogram ini menggambarkan adanya aktor yang berperan sebagai cutpoint yang menghubungkan antar aktor. Terdapat dua cutpoints yang tergambar yaitu aktor 8 (Ida Nurhayati) dan aktor 2 (Lusiani). Keduanya saling bertukar informasi mengenai pemotongan bahan, dan penghubung antar dua kelompok. Tanpa adanya kedua cutpoint ini informasi antara dua kelompok tidak dapat tersampaikan. Menurut hasil wawancara peneliti dengan
Ida Nurhayati yang akrab dipanggil Bu Ida pada 05 November 2019 di Jambangan 2b/6, ia mengatakan bahwa:

"Saya lebih sering ke $\mathrm{Bu}$ Tris soalnya $\mathrm{Bu}$ Tris yang mengarahkan desainnya dari pelanggan jadi potongan-potongannya dia yang tahu"

Pada Gambar IV.4. juga tergambar adanya peran hubs yang ditunjukkan kepada aktor nomor 9 yaitu Sunarno yang biasa akrab dipanggil Pak Mis. Peran hubs merujuk kepada Pak Mis karena ia memiliki koneksi paling banyak diantara aktor lainnya, jumlah koneksi yang terlihat adalah lima koneksi dari aktor dengan nomor 1-3-4-10-12. Lima aktor tersebut memilih Pak Mis karena ia mampu menyampaikan informasi mengenai pemotongan bahan kepada aktor yang membutuhkan informasi tersebut. Selain itu dikarenakan ia memiliki waktu luang ketika tidak ada pekerjaan yang dikerjakan. Pak Mis bekerja sebagai tukang bangunan dengan latar belakangnya hanya memiliki pendidikan hingga lulus Sekolah Dasar (SD).

Pada jaringan komunikasi Usaha Kecil dan Menengah (UKM) Tris Flower yang berfokus pada salah satu proses pengolahan sampah daur ulang, yaitu pemotongan bahan, terdapat 4 (empat) 
peranan yang terbentuk dari hasil interaksi anggota satu sama lain. Peranan yang terbentuk dalam jaringan ini adalahKomponen, Klik, Cutpoints, dan Hubs. Keempat peranan yang terlihat merupakan aktor yang memiliki andil dalam membangun UKM Tris Flower hingga menjadi sentra kerajinan daur ulang sampah kota Surabaya. Bukan hanya pengelola yang memiliki andil, namun anggota yang merupakan warga Kecamatan Jambangan pun memiliki andil dalam hal ini.

Sosiogram Jaringan Komunikasi dalam Penjahitan

$\mathrm{N}=12$

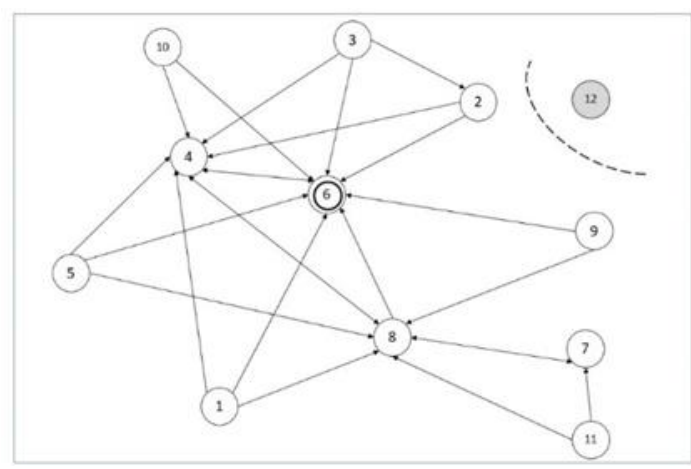

Gambar 5 Sosiogram Informasi Pengolahan Sampah Daur Ulang dalam proses Penjahitan

\section{Keterangan:}
a. $\bigcirc$ : Aktor / Komponen
b. $\theta$ : Cutpoints
c. $\bigcirc$ : Isolate / Pemencil
d. $\bigcirc$ :Hubs
e. $\rightarrow$ : Satu Arah
f. $\leftrightarrow$ : Dua Arah
g. - - : Batasan Klik
h. : Bridges

Pada Gambar 5., sosiogram tersebut menunjukkan bagaimana arah komunikasi yang terjadi dalam sebuah sistem jaringan dalam proses penyebaran informasi terkait penjahitan yang merupakan salah satu tahapan pengolahan sampah daur ulang di Usaha Kecil dan Menengah (UKM) Tris Flower Jambangan.

Dalam sosiogram ini menggambarkan relasi antara 12 komponen atau aktor yang tergabung dalam UKM Tris Flower. Jaringan ini tidak memiliki klik karena tidak memenuhi syarat dari klik itu sendiri. Namun, pada jaringan ini terdapat peran hubs yang ditujukan kepada aktor nomor 6 yaitu Misinem atau akrab dipanggil $\mathrm{Bu}$ Mis. Bu Mis mendapatkan peran hubs karena ia mendapatkan link yang paling banyak dibandingkan aktor lainnya yaitu sebanyak delapan link atau kontak. Alasan aktor nomor 1-2-3-4-5-8-9-10 memilih $\mathrm{Bu}$ Mis dalam mencari informasi mengenai penjahitan kerajinan daur ulang sampah ialah karena Bu Mis merupakan salah satu penjahit yang memiliki peralatan jahit dirumahnya dan ia biasanya diberikan bagian paling banyak dalam penjahitan. Menurut wawancara peneliti dengan aktor nomor 2 atau Lusiani pada 05 November 2019, ia mengatakan:

"Untuk penjahitan saya diskusi juga sama para penjahit seperti Bu Mis, 
$\mathrm{Bu}$ Ida, Bu Nur. Ya tapi lebih sering ke Bu Mis, soalnya rumahnya dekat dengan rumah saya. Karena rumahnya dekat itu tadi Bu Mis juga mudah ambil bahan bakunya di UKM."

Sebagai penjahit di UKM Tris Flower $\mathrm{Bu}$ Mis tidak hanya melakukan penjahitan setelah memiliki desain kerajinan daur ulang sampah. Namun, dalam prosesnya penjahit juga berdiskusi mengenai bahan baku tersebut bisa dijahit menggunakan mesin atau bahkan di jahit manual menggunakan tangan. Terkadang untuk bahan seperti goni memerlukan jahitan manual agar lebih kuat. Untuk itu alasan lain para aktor memilih $\mathrm{Bu}$ Mis dalam mencari informasi penjahitan karena $\mathrm{Bu}$ Mis dapat menyampaikan proses penjahitan dengan baik kepada aktor yang membutuhkan informasi tersebut.

Selain terdapat klik dan hubs pada jaringan ini terdapat peran isolate atau pemencil. Peran ini ditujukan pada aktor nomor 12 yaitu Catur. Isolate atau pemencil merupakan aktor yang tidak memiliki link atau kontak sama sekali dengan aktor lainnya. Menurut hasil wawancara peneliti dengan Catur pada 05 November 2019 di UKM Tris Flower, ia mengaku bahwa sejak pertama ia bergabung di UKM Tris Flower pada awal tahun 2019 ia belum mencoba atau melakukan proses pengolahan kerajinan daur ulang sampah yaitu proses penjahitan. Pada jaringan komunikasi Usaha Kecil dan Menengah (UKM) Tris Flower yang berfokus pada salah satu proses pengolahan sampah daur ulang, yaitu penjahitan, terdapat dua peranan yang terbentuk dari hasil interaksi anggota satu sama lain. Peranan yang terbentuk dalam jaringan ini adalahKomponen, Isolate / Pemencil, dan Hubs. Dalam sosiogram ini menunjukkan adanya Isolate yang tidak memiliki link dengan aktor manapun. Hal tersebut berarti Isolate tidak memiliki banyak andil dalam proses ini. Sedangkan 2 (dua)peranan yang terlihat merupakan aktor yang memiliki andil dalam membangun UKM Tris Flower hingga menjadi sentra kerajinan daur ulang sampah kota Surabaya. Bukan hanya pengelola yang memiliki andil, namun anggota yang merupakan warga Kecamatan Jambangan pun memiliki andil dalam hal ini.

Karakteristik / Ciri-Ciri Peranan di Usaha Kecil dan Menengah Tris Flower Karakteristik / Ciri-Ciri Cutpoints pada UKM Tris Flower

Peranan cutpoint memiliki arti aktor yang menjadi perekat di dalam jaringan. Berdasarkan hasil wawancara peneliti dengan responden atau anggota UKM Tris 
Flower terkait proses pengolahan daur ulang sampah, menghasilkan aktor nomor 7 (Nur Janati), 8 (Ida Nurhayati) dan 2 (Lusiani) sebagai peran cutpoints. Hal tersebut dikarenakan aktor-aktor memiliki ciri-ciri sebagai berikut:

\begin{tabular}{|l|l|l|l|}
\hline & \multicolumn{2}{|l|}{$\begin{array}{l}\text { Individu } \\
\text { yang } \\
\text { memiliki } \\
\text { Ciri-Ciri Cutpoint }\end{array}$} & $\begin{array}{l}\text { peran } \\
\text { cutpoint }\end{array}$ \\
\hline & $\mathbf{7}$ & $\mathbf{8}$ & $\mathbf{2}$ \\
\hline $\begin{array}{l}\text { Memiliki jabatan } \\
\text { sebagai Pengelola UKM } \\
\text { Tris Flower jabatan }\end{array}$ & & & \\
\hline $\begin{array}{l}\text { Memiliki kedekatan } \\
\text { sebagai Ketua RT 02 }\end{array}$ & & & \\
\hline $\begin{array}{l}\text { Memiliki } \\
\text { dengan Pengelola UKM } \\
\text { Tris Flower }\end{array}$ & & & \\
\hline $\begin{array}{l}\text { Memiliki pengalaman } \\
\text { dalam UKM Tris }\end{array}$ & & & \\
Flower sejak tahun 2008 & & & \\
\hline $\begin{array}{l}\text { Bekerja sebagai ibu } \\
\text { rumah tangga }\end{array}$ & & & \\
\hline
\end{tabular}

Tabel 1. Ciri-Ciri Cutpoint dalam Proses Pengolahan Daur Ulang Sampah

Pada Tabel 1. menunjukkan beberapa aktor yang terpilih sebagai peran cutpoint dengan karakternya masing-masing. Aktor nomor 7 yaitu Nur Janati menjadi cutpoint dalam proses pemilahan bahan baku karena Nur memiliki kedekatan dengan pengelola UKM Tris Flower yaitu aktor nomor 2 (Lusiani). Sehingga pencarian informasi mengenai pemilahan bahan baku yang diterima dari klik II (beranggotakan aktor nomor 7,8, dan 11) dapat diklarifikasi kepada pengelola UKM Tris
Flower yaitu aktor nomor 2 yang terdapat di klik I. Selain Nur Janati, aktor nomor 8 yaitu Ida Nurhayati menjadi cutpoint dalam proses perancangan model atau desain dan proses pemotongan karena Ida memiliki kedekatan dengan pengelola UKM Tris Flower yaitu Lusiani.

Sementara itu, pada proses pemotongan bahan aktor nomor 2 (Lusiani) dan aktor nomor 8 (Ida Nurhayati) terpilih sebagai peran cutpoint karena Lusiani memiliki jabatan sebagai pengelola UKM Tris Flower sehingga ia perlu melakukan koordinasi dengan aktor nomor 8 yaitu Ida Nurhayati dalam proses tersebut. Keduanya tergabung kedalam kelompok yang berbeda, aktor nomor 8 tergabung pada klik I sedangkan aktor nomor 2 tergabung pada klik II. Klik I memiliki lokasi di Jambangan RT 02, sedangkan klik II berlokasi di Jambangan RT 01. Hal tersebut mengakibatkan keduanya mewakili kelompoknya dalam mencari informasi mengenai pemotongan bahan tersebut, agar hasil barang pesanan kerajinan daur ulang sampah yang dikerjakan pada dua kelompok tersebut dapat seragam dan serupa.

Ketiga aktor yang terpilih dalam peran cutpoint berperan dalam menjadi penyalur informasi terhadap klik yang ada di dalam jaringan. Selain ketiganya bekerja sebagai 
pembersihan atau pencucian, perancangan model atau desain, pemotongan dan penjahitan) yang dimiliki oleh individuindividu tersebut.

Pada Tabel 2 juga menunjukkan bahwa aktor nomor 2 yaitu Lusiani terpilih menjadi Hubs pada proses pemilahan bahan baku dan perancangan model atau desain. Hal tersebut dikarenkan ia memiliki jabatan sebagai Pengelola UKM Tris Flower yang berarti Lusiani memiliki hubungan langsung dengan bank sampah dan pengepul sampah lainnya. Selain itu ia juga berhubungan langsung dengan pelanggan untuk menanyakan model yang diinginkan. Para anggota UKM Tris Flower lebih mempercayai Lusiani karena ia yang mengerti pesanan dari pelanggan.

Selain hal tersebut, juga dapat dilihat bahwa 3 orang aktor selain Lusiani menjadi peran hubs merupakan anggota dari UKM Tris Flower. Hal tersebut menunjukkan bahwa pengembangan UKM Tris Flower hingga menjadi sentra kerajinan daur ulang sampah kota Surabaya merupakan ada andil dari anggota UKM Tris Flower. Dimana pada tabel IV.14 juga menunjukkan bahwa para anggota Tris Flower juga merupakan warga dari Kecamatan Jambangan

Karakteristik / Ciri-Ciri Isolate pada UKM Tris Flower

\begin{tabular}{|c|c|}
\hline \multirow[t]{2}{*}{ Ciri-Ciri Isolate } & $\begin{array}{l}\text { Individu } \\
\text { yang } \\
\text { memiliki } \\
\text { peran } \\
\text { isolate }\end{array}$ \\
\hline & 12 \\
\hline $\begin{array}{l}\text { Memiliki jabatan sebagai } \\
\text { Sekretaris UKM Tris } \\
\text { Flower }\end{array}$ & \\
\hline $\begin{array}{l}\text { Bergabung dengan UKM } \\
\text { Tris Flower pada awal } \\
2019\end{array}$ & \\
\hline $\begin{array}{lr}\begin{array}{l}\text { Belum } \\
\text { melakukan }\end{array} & \text { pernah } \\
\text { penjahitan } & \text { proses } \\
\end{array}$ & \\
\hline $\begin{array}{lr}\text { Tidak } & \text { berhubungan } \\
\text { langsung } & \text { dengan } \\
\text { pelanggan pada proses } \\
\text { perancangan model atau } \\
\text { desain }\end{array}$ & \\
\hline
\end{tabular}

Tabel 3. Ciri-Ciri Isolate dalam Proses Pengolahan Daur Ulang Sampah

Berdasarkan tabel 3 menunjukkan terdapat dua aktor yang tidak memiliki link atau kontak sama sekali dengan responden yang lain. Menurut hasil wawancara peneliti terdapat beberapa ciri-ciri yang menunjukkan peran isolate pada penelitian ini. Pada aktor nomor 3 yaitu Muhammad Chandra ia memiliki jabatan Sekretaris di dalam UKM Tris Flower, selain itu ia tidak berhubungan dengan pelanggan pada proses perancangan model atau desain.

Sedangkan aktor nomor 12 yaitu Catur, ia merupakan anggota paling baru dimana ia baru bergabung dengan UKM Tris Flower pada awal tahun 2019. Hal tersebut juga mengakibatkan Catur belum memiliki pengalaman di dalam proses penjahitan. Mengingat proses penjahitan 
juga membutuhkan alat dan keahlian khusus, sedangkan alat jahit yang dimiliki UKM Tris Flower terbilang cukup terbatas sehingga Catur belum sempat melakukan proses tersebut.

Jika melihat tabel 3, dapat disimpulkan bahwa kedua aktor diatas merupakan aktor yang tidak memiliki andil dalam memajukan jaringan pada salah satu proses pengolahan daur ulang sampah. Meskipun begitu, keberadaan aktor tersebut memiliki andil pada proses pengolahan daur ulang lainnya. Hal tersebut menjelaskan bahwa Chandra dan Catur tetap memiliki andil dalam membangun UKM Tris Flower hingga ditetapkan mejadi sentra kerajinan daur ulang sampah kota Surabaya

\section{Kesimpulan}

Dalam penelitian ini terdapat peranan khusus dalam kelima proses pengolahan daur ulang sampah meliputi peranan sebagai Komponen/Aktor, Klik, Cutpoint, Isolate, Bridge, dan Hubs. Dalam setiap aktor yang terpilih dalam pernanan menunjukkan bahwa tidak hanya pemilik, pengelola dan sekretaris yang memiliki andil dalam membangun UKM Tris Flower hingga menjadi Sentra Kerajinan Daur Ulang Sampah Kota Surabaya. Namun, dari hasil tersebut dapat terlihat jika anggota-anggota yang merupakan warga dari Kecamatan Jambangan juga turut andil dalam membangun UKM Tris Flower. Beberapa anggota mendapatkan peran yang berpengaruh pada pembangunan UKM Tris Flower. Namun, statusnya sebagai sentra seharusnya menghasilkan beberapa Klik/ kelompok didalam jaringan-jaringan komunikasinya. Hal tersebut tidak terlihat pada penelitian ini yang hanya terdapat maksimal 2 (dua) Klik pada jaringannya.

\section{Referensi}

\section{BUKU}

Eriyanto. (2014). Analisis Jaringan Komunikasi. Jakarta: PRENADAMEDIA GROUP.

Kincaid, D. Lawrence \& Wilbur Schramm. (1978) . Azas-Azas Komunikasi Antar

$\begin{array}{llr}\text { Manusia. Jakarta: } & \text { LP3ES } \\ \text { bekerjasama dengan } & \text { East-West } \\ \text { Communication Institute. } & \end{array}$
Kriyantono, Rachmat. (2012). Teknik Praktis Riset Komunikasi. Jakarta: Kencana Prenadamedia Group.

Morissan, (2009). Teori Komunikasi Organisasi. Bogor: Ghalia Indonesia. Moerdijati, Sri. (2016). Pengantar Ilmu Komunikasi. Surabaya: PT Revka Petra Media. 
Muhammad, Arni. (2017). Komunikasi Organisasi. Jakarta: PT Bumi Aksara. Mulyana, Deddy. (2017). Ilmu Komunikasi Suatu Pengantar. Bandung: PT Remaja Rosdakarya Offset.

Pace, R. Wayne \& Don F. Faules. (2015). Komunikasi Organisasi: Strategi Meningkatkan Kinerja Perusahaan. Bandung: PT. Remaja Rosdakarya.

Ruliana, Poppy. (2014). Komunikasi Organisasi : Teori dan Studi Kasus. Jakarta: Rajawali Pers.

Effendy, Onong Uchjana. (2009). Human

Relation \& Public Relation. Bandung : CV. Mandar Maju.

Agustina, Tri Siwi. (2015). Kewirausahaan (Teori dan Penerapan Pada Wirausaha dan UKM di Indonesia. Jakarta: Mitra Wacana Media.

\section{JURNAL}

Hertanto, Dedy, dkk. (2016). "Analisis

Struktur Jaringan Komunikasi dan Peran Aktor dalam Penerapan Teknologi Budidaya Kentang”. Jurnal Habitat. 27 (2), 55-65

Cindoswari, A. R., (2016). "Analisis Struktur Jaringan Komunikasi Dalam Adaptadi Ekonomi, Sosial dan Budaya pada Paguyuban Babul
Akhirat di Kota Batam". Jurnal Komunikasi. X (2), 129-144

Fitriani. (2016). “Analisis Jaringan Komunikasi Informal “Adidas Team” di PT Damco Indonesia Jakarta Pusat". 15 (2), 275-285

Zulkarnain, dkk . (2015). "Jaringan Komunikasi dalam Kegiatan Produksi dan Pemasaran pada Pembudidaya Ikan di Kabupaten Kampar, Riau”. J. Sosek KP, 10 (1), 115-124

Pangestu, Michelle. (2015). “Jaringan Komunikasi di The Piano Institute Surabaya". Jurnal E-Komunikasi. 3 (2), 1-12

Zulfikar, M.Iqbal Sultan, Jeanny Maria Fatimah. (2013). "Pola Jaringan Komunikasi Kelompok dalam Menumbuhkan Solidaritas Aksi

Unjuk Rasa Mahasiswa di Kota Makassar”. Jurnal Komunikasi Kareba, 2 (4), 315-325

\section{REFERENSI INTERNET}

UKM Tris Flower. (2019). "Profil UKM Tris Flower" dari https://www.trisflower.com/profile$\underline{\text { ukm-tris-flower, diakses pada tanggal }}$ 21 Mei 2019

Kompas Internasional. (2018). "Sampah Plastik Dunia Dalam Angka" dari https://internasional.kompas.com/rea 
d/2018/11/21/18465601/sampah-

plastik-dunia-dalam-angka?page=all

,diakses pada tanggal 27 Agustus

2019

\section{LAPORAN BERKALA}

Badan Pusat Statistik Indonesia. (2018).

Statistik Lingkungan Hidup Indonesia

2018: Pengelolaan Sampah di

Indonesia. Indonesia; Author 